\title{
Protein Transfer in Mainstream and Sidestream Cigarette Smoke*
}

\author{
Richard Voisine, France Côté, Jules Verreault and Andrew Porter* \\ Imperial Tobacco Canada Ltd, Montreal, Quebec, Canada
}

\section{SUMMARY}

Protein transfer in tobacco smoke has been studied using the protease, Savinase ${ }^{\mathrm{TM}}$, as a model protein. Mainstream and sidestream smoke were collected from cigarettes to which Savinase had been added at various concentrations. Savinase was extracted from the smoke condensate with an organic solvent system before being precipitated and further identified by denaturing polyacrylamide gel electrophoresis (SDS-PAGE) and Western immunoblotting. The detection limit of the method, based on addition of Savinase to the smoke condensate, was $25 \mu \mathrm{g}$ in mainstream and 100 $\mu \mathrm{g}$ in sidestream smoke. At a Savinase concentration of $6000 \mu \mathrm{g}$ per gram of tobacco, the methodology allows the detection of protein transfer as low as $0.009 \%$ and $0.054 \%$ in mainstream and sidestream smoke, respectively. Using this approach, it was shown that there is no detectable Savinase in the mainstream and sidestream smoke of filtered and unfiltered cigarettes containing up to $6000 \mu \mathrm{g}$ of Savinase per gram of tobacco. These facts strongly suggest that there is no significant transfer of protein from tobacco into cigarette smoke. [Beitr. Tabakforsch. Int. 21 (2004) 9-14]

\section{ZUSAMMENFASSUNG}

Der Proteintransfer in den Tabakrauch wurde mit dem Protease Savinase ${ }^{\mathrm{TM}}$ Modellprotein untersucht. Der Hauptstrom- und Nebenstromrauch von Zigaretten, denen Savinase in unterschiedlichen Konzentrationen zugesetzt worden war, wurde gesammelt. Savinase wurde mit einem organischen Lösungsmittel aus dem Rauchkondensat extrahiert und ausgefällt und nach Auftrennung mit Polyacrylamid-Gel-Elektrophorese (SDS-PAGE) mittels Immunoblotting selektiv nachgewiesen. Die Nachweisgrenze dieser Methode, die sich aus der Zugabe der Savinase zum Rauchkondensat ergibt, lag im Hauptstromrauch bei $25 \mu \mathrm{g}$ und im Nebenstromrauch bei $100 \mu \mathrm{g}$. Bei einer Savinase Konzen- tration von $6000 \mu \mathrm{g} / \mathrm{g}$ Tabak ermöglicht die Methode den Nachweis eines Transfers von Proteinen von $0.009 \%$ in den Hauptstromrauch und von $0.054 \%$ in den Nebenstromrauch. Mit dieser Methode ließ sich zeigen, dass im Hauptstrom- und Nebenstromrauch von Filterzigaretten und filterlosen Zigaretten, bei denen bis zu $6000 \mu \mathrm{g}$ Savinase pro Gramm Tabak hinzugefügt wurde, keine Savinase vorhanden war. Diese Ergebnisse legen die Vermutung nahe, dass kein signifikanter Transfer von Proteinen aus dem Tabak in den Zigarettenrauch stattfindet. [Beitr. Tabakforsch. Int. 21 (2004) 9-14]

\section{RESUME}

Cette étude du transfert des protéines dans la fumée de cigarette a été réalisée en utilisant une protéase, la Savinase $^{\mathrm{TM}}$, comme protéine modèle. Différentes concentrations de Savinase ont été ajoutées à des cigarettes et les condensats de leurs fumées principales et secondaires ont été recueillis. La Savinase a été extraite des condensats de fumée par précipitation dans un mélange de solvants organiques et identifiée par Western immuno-buvardage après séparation des protéines par électrophorèse dénaturante sur gel de polyacrylamide (SDS-PAGE). La limite de détection de cette méthode est de $25 \mu \mathrm{g}$ dans la fumée principale et de $100 \mu \mathrm{g}$ dans la fumée secondaire et a été établie sur la base de l'addition de Savinase dans le condensat de fumée. A une concentration de $6000 \mu \mathrm{g}$ de Savinase par gramme de tabac, la méthode développée permet la détection d'un transfert de protéines aussi bas que $0.009 \%$ dans la fumée principale et de $0.054 \%$ dans la fumée secondaire. Cette approche a permis de démontrer que la Savinase n'était pas détectée dans les fumées principales et secondaires de cigarettes avec ou sans filtres et contenant jusqu'à $6000 \mu \mathrm{g}$ de Savinase par gramme de tabac. Ces faits suggèrent fortement qu'il n'y a pas de transfert significatif de protéines du tabac dans la fumée de cigarette. [Beitr. Tabakforsch. Int. 21 (2004) 9-14] 
Table 1. Specifications of cigarettes used.

\begin{tabular}{l|c}
\hline Parameter & Specification \\
\hline Cigarette length (mm) & 84 \\
Circumference (mm) & 25 \\
Filter length (mm) & 20 \\
Tipping length (mm) & 24 \\
Total tobacco weight (mg) & 799 \\
Tobacco weight burned (mg) & 699 \\
Ventilation (\%) $_{\text {"Tar"/nicotine/CO (mg) }}^{\text {a }}$ & 0 \\
Cigarette pressure drop (mm WG) $^{(m)}$ & $15 / 1.4 / 17$ \\
\hline
\end{tabular}

a Smoking regime: Standard (ISO) (35 mL, 2 s, 1 puff/min).

\section{INTRODUCTION}

Before flue-curing, tobacco leaf contains intracellular and cell wall structural proteins at a nitrogen level of less than $1 \%$ on a dry weight basis (6). Due to their high molecular weights, proteins would not be expected to transfer intact to smoke. However, there have been some reports of protein or proteinaceous materials in smoke condensate in studies concerning the composition of brown pigments and the immunogenicity of smoke. BECKER and his collaborators published several papers describing an $18 \mathrm{kD}$-tobaccoglycoprotein (TGP) extracted from the smoke condensate of University of Kentucky 1R1 cigarettes $(1,2,3)$. However, BICK et al. (4) were unable to isolate TGP with the procedure described by BECKER et al. (1) and suggested that a linear polyacrylate and not a TGP was isolated. GLEMBOCKI and BECKER (5) also reported detecting a $60 \mathrm{kD}$ protein in smoke condensate. In 1978, SHEEN and BURTON (9) reported that acid hydrolysis of the brown pigment fraction extracted from the smoke condensate of 1R1 cigarettes yielded amino acids, which indicated the possible presence of proteins.

It is becoming more important to quantify the potential for protein transfer particularly in the evaluation of transgenic or enzyme-treated tobaccos that could be used for cigarette making, and the debate surrounding the possibility of allergic responses to cigarette smoke. Accordingly, an original method was developed for monitoring a model protein and its fragments in smoke condensate. Savinase (7) was chosen as the model protein because specific antibodies against Savinase were readily available in our laboratory and because numerous Savinase autolysis fragments contaminating the Savinase preparation could be monitored. Savinase (E.C. 3.4.21.14) is a bacterial serine protease of the Subtilisin family with broad specificity for peptide bonds. The pure enzyme is a globular protein composed of 269 amino acids in a single chain. The molecular weight is $27.6 \mathrm{kD}$.

By using specific antibodies to Savinase as a powerful detection tool, we have studied the potential transfer of Savinase in smoke by monitoring its presence in sidestream and mainstream smoke from cigarettes containing the model protein.

\section{MATERIALS AND METHODS}

\section{Cigarettes and smoking conditions}

Commercial, $84 \mathrm{~mm}$ Canadian filter cigarettes (Table 1) were used throughout the study. Savinase was added directly to the smoke condensate for studies to optimise extraction. Savinase was added to cigarettes that were smoked for possible transfer of Savinase to the smoke.

Mainstream smoke condensate was obtained by smoking cigarettes on a 15-port capillary-press smoking engine (Heinr. Borgwaldt, Germany) using the following smoking parameters: puff volume, $35 \mathrm{~mL}$; puff interval, $2 \mathrm{sec}$; puff frequency, $1 \mathrm{~min}^{-1}$; and butt length, $28 \mathrm{~mm}$. The results were corrected for the "tar" condensation efficiency of the capillary press, which was $47 \%$ compared with collection using a Cambridge filter.

Sidestream smoke condensate was collected from 8 cigarettes at a time by pumping the smoke at $10.6 \mathrm{~L} / \mathrm{min}$ into a funnel connected to a 92-mm Cambridge filter. The efficiency of the collection device used was $55 \%$ compared with a fishtail chimney (8). Usually, $1.4 \mathrm{~g}$ of smoke condensate was collected. For mainstream smoke this required 140 cigarettes and for sidestream smoke, 80 cigarettes.

\section{Determination of the best solvent extraction system}

The insolubility of different proteins in various organic solvent mixtures was assessed by measuring the transmittance of the protein-solvent mixture at $590 \mathrm{~nm}$ with a turbidimeter (Biolog, Model 21906). Bovine serum albumin (BSA) (Sigma, Oakville, ON, Canada), carbonic anhydrase (Sigma), trypsin inhibitor (Sigma), $\alpha$-lactalbumin (Sigma) and lysozyme (Sigma) were used for testing the capability of each solvent mixture for precipitating protein. For each protein tested, $45 \mu \mathrm{L}$ of a $100 \mathrm{mg} / \mathrm{mL}$ aqueous protein solution was added to test tubes containing $9 \mathrm{~mL}$ of the following solvent or solvent mixtures: dimethylsulphoxide (DMSO), methanol, DMSO:methanol mixtures in the following proportions: $1: 1,1: 2,1: 4,2: 1,4: 1 \quad(\mathrm{v} / \mathrm{v})$; methanol:chloroform mixtures: $1: 1,2: 1,4: 1(\mathrm{v} / \mathrm{v})$; and DMSO:chloroform mixtures: 1:1, 1:1.5, 1:2(v/v). The insolubility of the protein in each solvent or solvent mixture was rated according to the turbidity level of the solution: high (transmittance from $0 \%$ to $75 \%$ ), medium $(76 \%$ to $85 \%$ ), low ( $86 \%$ to $95 \%$ ), or no precipitation $(96 \%$ to $100 \%)$. The solubilities of $0.1 \mathrm{~g}$ smoke condensate in $3 \mathrm{~mL}$ of methanol, DMSO, DMSO:chloroform 1:2(v/v), or methanol:chloroform 1:1, 2:1, 4:1 (v/v) were also qualitatively evaluated as high, medium or low.

\section{Extraction of Savinase from mainstream smoke condensate}

Mainstream smoke condensate from 70 cigarettes (without Savinase added to the tobacco) was collected in a $40 \mathrm{~mL}$ teflon tube. Fifty $\mu \mathrm{L}$ of an aqueous solution containing 25 or $50 \mu \mathrm{g}$ of Savinase (Savinase 16, Novozymes, Bagswaerd, Denmark) was added to the condensate. Smoke condensate from a further 70 cigarettes was collected and added to the condensate/enzyme mixture to completely cover the enzyme solution. The smoke condensate was then solubilised by vortexing with $23 \mathrm{~mL}$ of DMSO:chloroform 
$(1: 2 \mathrm{v} / \mathrm{v})$ per gram of smoke condensate. Twenty mg lysozyme were added to trigger protein precipitation. Precipitated proteins were collected by filtration on a $1 \mu \mathrm{m}$ PTFE filter and retained proteins were solubilised in $4 \mathrm{~mL}$ of extraction buffer [10 mM Tris, $1 \mathrm{mM} N, N^{\prime}$-1,2-ethanediylbis[ $N$-(carboxymethyl)glycine] (EDTA), 3.5\% sodium dodecylsulphonate (SDS), $\mathrm{pH} 8.5$ ] by sonication for $1.5 \mathrm{~h}$. The extract was separated by denaturing polyacrylamide gel electrophoresis (SDS-PAGE) and electro-transferred onto a nitrocellulose (NC) membrane. Savinase was detected by immunostaining with a specific antibody as described in the section "Monitoring of Savinase". The negative control used was an extract of smoke condensate from 140 of the same cigarettes with no Savinase added.

\section{Extraction of Savinase from sidestream smoke condensate}

Sidestream smoke condensate from 24 cigarettes (without Savinase added to the tobacco) was collected on a Cambridge filter. One hundred $\mu \mathrm{g}$ of Savinase was added to the filter and the smoke of another 56 cigarettes was collected on the same filter. The saturated filter was cut into three pieces and sonicated with $50 \mathrm{~mL}$ DMSO:methanol (1:2 v/v) for $45 \mathrm{~min}$. The filter was squeezed and the extract solution was divided equally into two $40 \mathrm{~mL}$ teflon tubes and centrifuged at $3000 \mathrm{~g}$ for $5 \mathrm{~min}$. The supernatant was carefully recovered and $20 \mathrm{mg}$ lysozyme was added to trigger protein precipitation. Precipitated proteins were collected by filtration on a $1 \mu \mathrm{m}$ Teflon filter and retained proteins were solubilised in $4 \mathrm{~mL}$ extraction buffer by sonication for $1.5 \mathrm{~h}$. The extract was separated by denaturing SDS-PAGE, and electro-transferred onto an NC membrane. Savinase was detected by immunostaining with a specific antibody as described below. The extract of sidestream smoke condensate from 80 of the same cigarettes with no Savinase added was used as a negative control.

\section{Monitoring of Savinase}

SDS-PAGE was carried out under reducing conditions using $16.5 \%$ tricine precast gels (Ready gel SDS, Bio-Rad, Hercules, CA). Kaleidoscope Polypeptides Standards in the range of 3.5 to $32 \mathrm{kD}$ (Bio-Rad) were used to locate the Savinase and to assess the quality of the electrophoretic protein separation.

Proteins from electrophoresis gels were transferred onto a $0.2 \mu \mathrm{m}$ NC membrane according to TowBIN et al., (10). Transferred proteins were fixed with $0.2 \%$ (v/v) glutaraldehyde in phosphate-buffered-saline (PBS) $[137 \mathrm{mM}$ $\left.\mathrm{NaCl}, 1.5 \mathrm{mM} \mathrm{NaH} \mathrm{PO}_{4} \cdot \mathrm{H}_{2} \mathrm{O}, 8.2 \mathrm{mM} \mathrm{Na}_{2} \mathrm{PO}_{4}\right]$ to ensure that small peptides were not eluted during staining. Unbound sites on the NC membrane were blocked using 5\% non-fat dried milk in PBS for $1 \mathrm{~h}$. The membrane was washed twice ( 2 min) in PBS containing $0.1 \%$ Tween 20 (PBS-T), and then incubated for $1 \mathrm{~h}$ with a rabbit antiSavinase antibody preparation diluted 1:5000 in PBS-T. After being washed three times for $5 \mathrm{~min}$, the membrane was incubated for $1 \mathrm{~h}$ with biotin-SP-conjugated Affinipure goat anti-Rabbit IgG (H+L) (Jackson ImmunoResearch Laboratories, West Grove, PA) diluted 1:10 000 (v/v) in PBS-T. After washing 3 times in PBS-T, the membranes were incubated for $1 \mathrm{~h}$ with streptavidin-horseradish per- oxydase conjugate (Amersham Biosciences, Piscataway, NJ) diluted 1:5000 (v/v) in PBS-T. The resulting blot was washed in PBS-T for $15 \mathrm{~min}$, before the protein bands were revealed colorimetrically by incubating in a solution of OPTI-4CN (Bio-Rad) for 30 to $60 \mathrm{~min}$ depending on the background intensity. Finally, the membrane was washed with water for $15 \mathrm{~min}$ to stop the reaction.

The Savinase bands were approximately quantified by comparing their intensities with those of various known loadings of Savinase applied to the same electrophoresis gel. The lowest amount of Savinase that could be visualised on the blots was $1 \mathrm{ng}$.

\section{Savinase transfer to cigarette smoke}

Two or three $40 \mu \mathrm{L}$ aliquots of a commercial liquid Savinase preparation (Savinase 16, $40 \mathrm{mg} / \mathrm{mL}$, Novozyme) were injected into cigarette tobacco rods using a $50 \mu \mathrm{L}$ syringe to obtain Savinase concentrations of 4000 and 6000 $\mu \mathrm{g} / \mathrm{g}$ respectively. The mainstream and sidestream smoke condensates of each cigarette type were analysed at least in triplicate for traces of Savinase as described above.

\section{RESULTS AND DISCUSSION}

\section{Detection of Savinase in smoke}

A method for monitoring the presence of Savinase in smoke has been developed. This method involves extraction of proteins from smoke condensate and the use of SDS-PAGE followed by a Western blotting to identify Savinase. BECKER and collaborators (1) who reported the detection of a $18 \mathrm{kD}$-tobacco-glycoprotein in smoke condensate used a buffer in which the protein was soluble while the smoke condensate was not. Attempts in our laboratory to use this approach were not satisfactory. Protein separation during SDS-PAGE was severely affected by smoke condensate compounds contaminating the protein sample. For this reason we tried the opposite approach: insolubilising the protein while solubilising much of the smoke condensate before extracting the protein and solubilising it. Different solvents and solvent mixtures were screened to find which one would solubilise the greatest proportion of tobacco smoke condensate while precipitating proteins over a broad range of molecular weights. The goal was to have a general extraction procedure for proteins in smoke condensate that gives samples suitable for SDSPAGE separation. A 1:2 mixture of DMSO and chloroform was found to be the best combination (Table 2). However, the very low Savinase concentration resulting from solubilising smoke condensate that contained only $25 \mu \mathrm{g}$ of Savinase made precipitation impossible. It was necessary to add a co-precipitating agent (20 $\mathrm{mg}$ of protein) to the smoke condensate-solvent mixture in order to trigger protein precipitation.

Bovine serum albumin and lysozyme were tested as coprecipitating agents. Both proteins gave satisfactory results. However, the resulting high concentration of the added protein caused a weak non-specific recognition of the coprecipitating protein by rabbit anti-Savinase antibodies. Both BSA $(66 \mathrm{kD})$ and lysozyme $(14.3 \mathrm{kD})$ could be visu- 
Table 2. Effect of various solvent mixtures on protein precipitation and solubilisation of smoke condensate ${ }^{a}$.

\begin{tabular}{|c|c|c|c|c|c|c|}
\hline \multirow[b]{2}{*}{ Solvent system ${ }^{b}$} & \multirow[b]{2}{*}{$\begin{array}{c}\text { Condensate } \\
\text { solubility }\end{array}$} & \multicolumn{5}{|c|}{ Degree of protein precipitation } \\
\hline & & $\begin{array}{l}\text { Lactalbumin } \\
(14.2 \mathrm{kD})\end{array}$ & $\begin{array}{c}\text { Lysozyme } \\
(14.3 \mathrm{kD})\end{array}$ & $\begin{array}{l}\text { Trypsin inhibitor } \\
(20.1 \mathrm{kD})\end{array}$ & $\begin{array}{c}\text { Carbonic anhydrase } \\
(29 \mathrm{kD})\end{array}$ & $\begin{array}{c}\mathrm{BSA} \\
(66 \mathrm{kD})\end{array}$ \\
\hline D & +++ & - & - & - & - & - \\
\hline M & ++ & ++ & - & +++ & +++ & +++ \\
\hline D:M 1:1 & Not tested & - & - & +++ & +++ & +++ \\
\hline D:M 1:2 & Not tested & - & - & +++ & +++ & +++ \\
\hline D:M 1:4 & Not tested & - & - & +++ & +++ & +++ \\
\hline D:M 2:1 & Not tested & - & - & - & +++ & + \\
\hline D:M 4:1 & Not tested & + & - & - & +++ & +++ \\
\hline M:C 1:1 & +++ & +++ & - & +++ & +++ & + \\
\hline M:C 2:1 & ++ & +++ & - & +++ & +++ & + \\
\hline M:C 4:1 & ++ & +++ & - & +++ & +++ & ++ \\
\hline D:C 1:1 & Not tested & + & - & + & +++ & +++ \\
\hline D:C 1:1.5 & Not tested & ++ & - & +++ & +++ & +++ \\
\hline D:C 1:2 & +++ & +++ & + & +++ & +++ & +++ \\
\hline
\end{tabular}

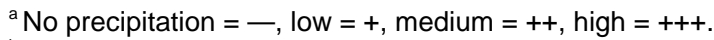

${ }^{\mathrm{b}} \mathrm{D}=\mathrm{DMSO}, \mathrm{M}=$ methanol, $\mathrm{C}=$ chloroform.

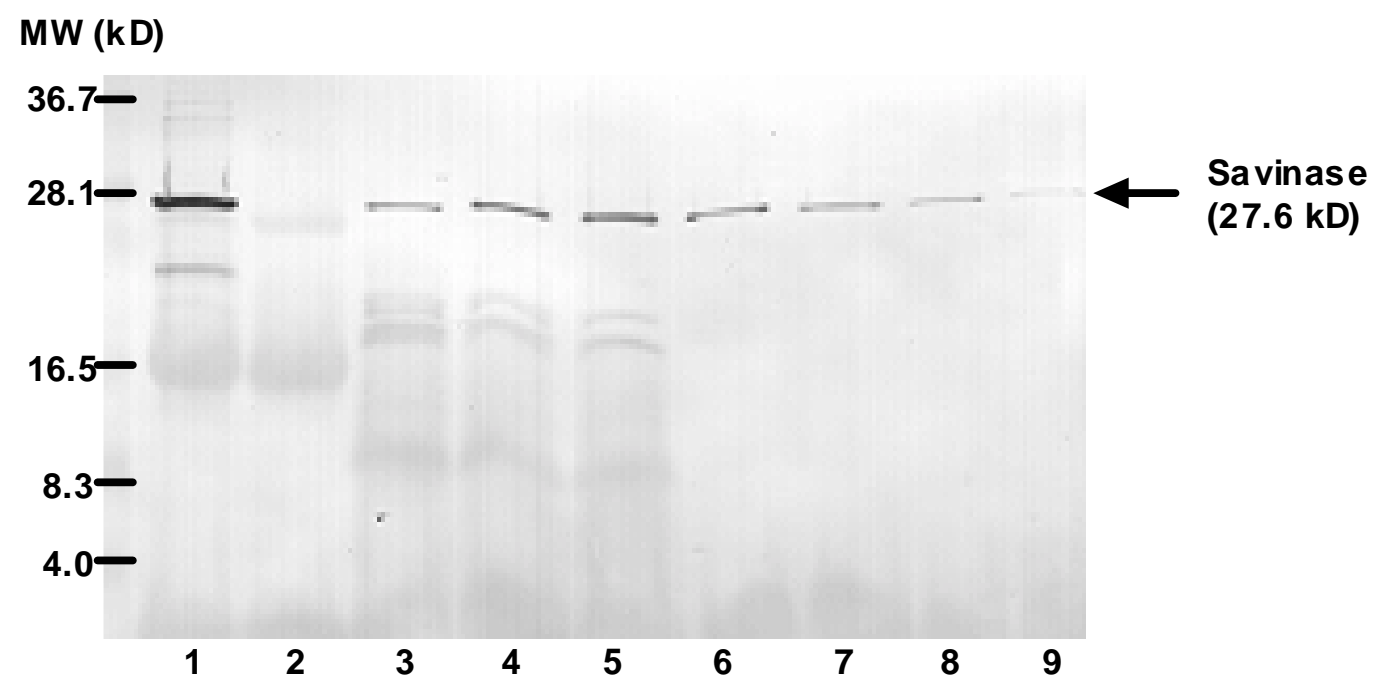

Figure 1. Typical detection by Western immunoblotting of Savinase added to mainstream smoke condensate and extracted with DMSO:chloroform (1:2) and with the addition of $\mathbf{2 0}$ mg lysozyme to trigger protein precipitation. Lane 1:100 $\mu \mathrm{g}$ of Savinase extracted without smoke condensate; lane 2: negative control - smoke condensate; lanes 3 and 5: $100 \mu \mathrm{g}$ of Savinase extracted from smoke condensate; lanes 6 to 9: 10, 5, 2.5, $1.25 \mathrm{ng}$ of Savinase standards (without lysozyme).

alised on the immunoblots after a long development time because they are at a very high concentration. Lane 2 in Figure 1 shows that lysozyme has been detected. However, since its molecular weight is lower than that of Savinase, it does not interfere with Savinase detection and is therefore suitable for the extraction procedure.

Figure 1 shows a typical detection of Savinase by Western immunoblotting after its extraction from mainstream smoke condensate. The assay can consistently detect levels of $25 \mu \mathrm{g}$ of Savinase added to $1.4 \mathrm{~g}$ of smoke condensate generated using a capillary press smoking machine. Trapping smoke condensate on a Cambridge filter reduced the sensitivity of the assay to $100 \mu \mathrm{g}$ of Savinase because it was more difficult to recover Savinase from the Cambridge filter than from free smoke condensate.

The fact that combustion takes place during smoking makes transfer of a large intact protein unlikely. However, it might be hypothesised that protein fragments might transfer. The present method allows detection of Savinase fragments resulting from autolysis (Figure 2).

\section{Mainstream smoke}

To assess protein transfer in mainstream smoke, a total of 140 cigarettes injected with 4000 or $6000 \mu \mathrm{g}$ of Savinase per gram of tobacco were smoked to generate about $1.4 \mathrm{~g}$ of each smoke condensate using the capillary press smoking machine. The mainstream smoke for each cigarette type was analysed and in no case was Savinase detected (Table 3 ). The upper limit of transfer can be calculated as follows: from Table 1, $699 \mathrm{mg}$ of tobacco are burned for each cigarette smoked. At a concentration of $6000 \mu \mathrm{g}$ of Savinase per gram of tobacco, this tobacco contains $4.2 \mathrm{mg}$ of Savinase. To produce $1.4 \mathrm{~g}$ of condensate, 140 cigarettes 


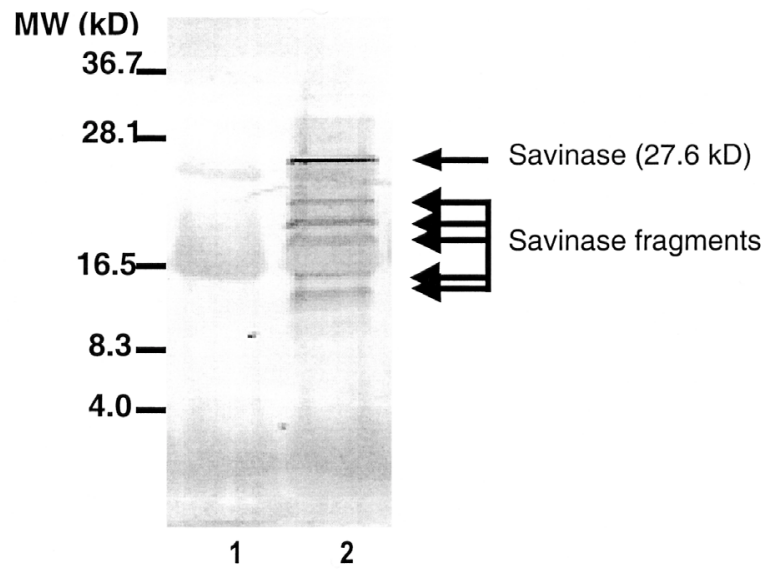

Figure 2. Detection by Western immunoblotting of Savinase and Savinase fragments extracted from smoke condensate with DMSO:chloroform (1:2) and with the addition of $20 \mathrm{mg}$ lysozyme to trigger protein precipitation. Lane 1: negative control -smoke condensate; lane 2: $25 \mu \mathrm{g}$ of autolysed Savinase extracted from smoke condensate. were smoked and therefore a total of $(140 \times 4.2) 588 \mathrm{mg}$ of Savinase is potentially available for transfer. Since the method can detect $25 \mu \mathrm{g}$ of Savinase in $1.4 \mathrm{~g}$ of condensate, transfer efficiencies down to $0.009 \%$ could be measured after correcting by a factor of $47 \%$.

Smoke from cigarettes with their filters removed was also tested for traces of Savinase. The protein was not detected in smoke from unfiltered cigarettes containing $6000 \mu \mathrm{g}$ of Savinase per gram of tobacco (Figure 3a). However, Savinase was detected in one of six experiments in smoke from unfiltered cigarettes containing $4000 \mu \mathrm{g}$ of Savinase per gram of tobacco. Further investigation revealed that this observation was an artefact caused by the transfer of tobacco fragments into the internal cavity of the capillary press smoking machine.

\section{Sidestream smoke}

Protein transfer in sidestream smoke was determined in cigarettes injected with $6000 \mu \mathrm{g}$ of Savinase per gram of tobacco. The relative limit of detection was $0.054 \%$ protein

Table 3. Detection of Savinase in mainstream cigarette smoke

\begin{tabular}{|c|c|c|c|c|}
\hline \multirow[b]{2}{*}{ Cigarette } & \multirow[b]{2}{*}{ Treatment } & \multirow{2}{*}{$\begin{array}{c}\text { Savinase content } \\
\text { ( } \mu \mathrm{g} \text { of Savinase/g of tobacco) }\end{array}$} & \multicolumn{2}{|c|}{ Savinase detection } \\
\hline & & & Mainstream smoke & Sidestream smoke $^{a}$ \\
\hline Commercial KS cigarette & Injection of Savinase & 4000 & No & $N / D$ \\
\hline Commercial KS cigarette & Injection of Savinase & 6000 & No & No \\
\hline $\begin{array}{l}\text { Commercial KS cigarette - filter } \\
\text { removed }\end{array}$ & Injection of Savinase & 4000 & No & $\mathrm{N} / \mathrm{D}$ \\
\hline $\begin{array}{l}\text { Commercial KS cigarette - filter } \\
\text { removed }\end{array}$ & Injection of Savinase & 6000 & No & $\mathrm{N} / \mathrm{D}$ \\
\hline
\end{tabular}

${ }^{a} \mathrm{~N} / \mathrm{D}=$ Not determined

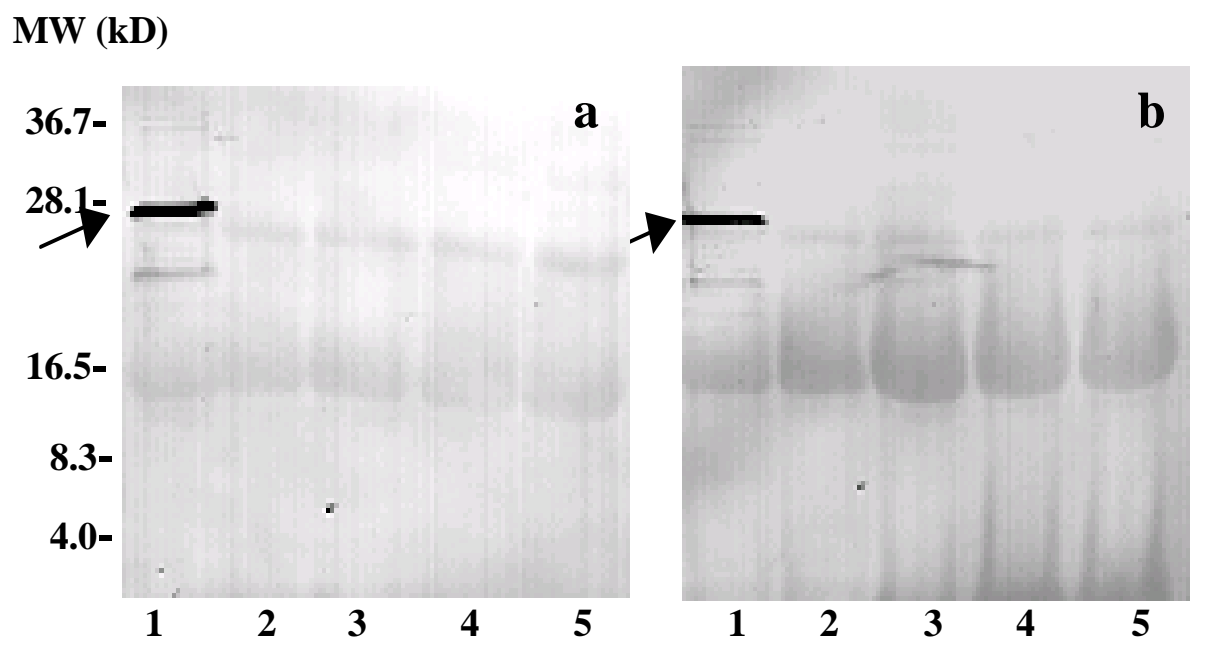

Figure 3. Protein transfer in a) mainstream and b) sidestream smoke extracted with DMSO:chloroform (1:2) and with the addition of $20 \mathrm{mg}$ lysozyme to trigger protein precipitation. Lanes 1a and 1b: positive control - $100 \mu \mathrm{g}$ of Savinase extracted without smoke condensate, Lanes $2 \mathrm{a}$ and $2 \mathrm{~b}$ : negative control - smoke condensate; lanes 3 to $5 \mathrm{a}$ : mainstream smoke condensate from unfiltered cigarettes injected with $6000 \mu \mathrm{g}$ of Savinase per gram of tobacco; lanes 3 to 5b: sidestream smoke condensate of cigarettes injected with $6000 \mu \mathrm{g}$ of Savinase per gram of tobacco. 
transfer. This limit was calculated as follows: the method can detect $100 \mu \mathrm{g}$ of Savinase in $1.3 \mathrm{~g}$ of TPM, obtained by smoking 80 cigarettes containing $4.2 \mathrm{mg}$ of Savinase per cigarette. The results were corrected by a factor of $55 \%$, which is the efficiency of the collection device used compared with a fishtail chimney. Protein transfer was not detected in sidestream smoke from cigarettes containing $6000 \mu \mathrm{g}$ of Savinase per gram of tobacco (Table 3 and Figure $3 \mathrm{~b}$ ) which indicates that protein transfer, if any, was very low.

\section{CONCLUSION}

To our knowledge, this is the first study on exogenous protein transfer in tobacco smoke making use of immunodetection techniques. These investigations have shown that if protein does transfer into mainstream smoke it would be at a level of less than $0.009 \%$. The cigarette filter does not seem to have a major impact on protein transfer, since removing the cigarette filter did not result in measurable smoke protein. A lack of protein transfer was also found for sidestream smoke even when high levels of residual Savinase were present on tobacco. The detection methodology used in this study was limited to the detection of Savinase. Other protein models could be studied if specific antibodies are used for detection.

Several papers $(1,2,3,5,9)$ reported the presence of protein in smoke. These studies all used non-filtered (Kentucky Reference 1R1) cigarettes. In our present studies we have shown that tobacco particles can be released from nonfiltered cigarettes and be trapped with the condensate. We can only speculate that in the earlier studies tobacco particles or dust may have been eluted from the 1R1 cigarettes during smoking thus contaminating the condensate.

\section{REFERENCES}

1. Becker, C.G., T. Dubin, and H.P. Wiedemann: Hypersensitivity to tobacco antigen; Proc. Natl. Acad. Sci. USA. 73 (1976) 1712-1716.

2. Becker, C.G. and T. Dubin: Activation of factor XII by tobacco glycoprotein; J. Exp. Med. 46 (1977) 457-467.

3. Becker, C.G., R. Levi, and J. Zavecz: Induction of IgE antibodies to antigen isolated from tobacco leaves and from cigarette smoke condensate; Am. J. Pathol. 96 (1979) 249-254.
4. Bick, R.L., R.L. Stedman, P.L. Dronick, and E. Hillman: Studies related to tobacco glycoprotein: A claimed activator of coagulation, fibrinolysis, complement, kinin and a claimed allergen; Clin. Res. 29 (1981) 178A.

5. Glembocki, D. and C. Becker: Flavimonas oryzihabitans isolated from cigarette tobacco yields a protein that is cross reactive with a protein in cigarette smoke condensate; FASEB J. 11(1997) 543A.

6. Leffingwell, J.C.: Leaf chemistry. 8A Basic chemical constituents of tobacco leaf and differences among tobacco types; in: Tobacco production, chemistry and technology, edited by D.L. Davis and M.T. Nielsen, Blackwell Science, London, UK, 2002, pp.265-284.

7. Outtrup, H. and C.O.L. Boyce: Microbial proteinases and biotechnology; in: Microbial enzymes and biotechnology, edited by W.M. Fogarty and C.T. Kelly, Elseiver Applied Science, London, UK, 1990, pp 227-254.

8. Proctor, J., C. Martin, J.L. Beven and H.F. Dymond: Evaluation of an apparatus for the collection of sidestream tobacco smoke; Analyst 113 (1988) 1509-1513.

9. Sheen, S.J. and H.R. Burton: Amino acid composition in soluble tobacco fractions containing brown pigments; J. Agric. Food Chem. 26 (1978) 380-385.

10. Towbin, H., T. Staehlin and J. Gordon: Electrophoretic transfer of proteins from polyacrylamide gels to nitrocellulose sheets: procedure and some applications; Proc. Nat. Acad. Sci. USA 76 (1979) 4350-4354.

Address for correspondence

Andrew Porter

Imperial Tobacco Canada Ltd

Montreal, Quebec H4C 3P6

Canada

E-mail:aporter@itl.ca 